\title{
Association of XPD Lys751Gln polymorphism with head and neck cancer susceptibility: evidence from 11,443 subjects
}

Hai Lin', Dong Lin ${ }^{2}$ and Chunquan Zheng ${ }^{1 *}$

\begin{abstract}
Background: Whether the single nucleotide polymorphism (SNP) Lys751Gln of xeroderma pigmentosum group D (XPD) gene increases susceptibility to head and neck cancer (HNC) is controversial and undetermined. Therefore, we conducted this meta-analysis to systematically assess the possible association between them.

Methods: The OVID, Medline, Embase, Pubmed, Web of Science databases were searched to identify the eligible studies. The odds ratio (OR) with $95 \%$ confidence interval $(95 \% \mathrm{Cl})$ were used to assess the strength of association.

Results: A total of 11,443 subjects from eighteen studies were subjected to meta-analysis. Overall, XPD Lys751Gln polymorphism had no association with increased HNC risk under all five genetic models $(P>0.05)$. In the subgroup analysis by ethnicity and source of controls, still no significant association was found under five genetic models $(\mathrm{P}>0.05)$. In the subgroup analysis by cancer type, XPD Lys751Gln polymorphism had statistically significant association with elevated laryngeal cancer (LC) and nasopharyngeal cancer (NPC) risk under heterozygous comparison and dominant model $(P<0.05)$ and borderline significantly increased risk was found under allele contrast for $L C$ and NPC. Carriers of Lys allele and Lys/Lys genotype may be associated with elevated LC and NPC risk.

Conclusions: There is overall lack of association between XPD Lys751GIn polymorphism and HNC risk under all five genetic models and still no significant association was found in the subgroup analysis by ethnicity and source of controls. However, XPD Lys751GIn polymorphism was significantly associated with susceptibility to LC and NPC and the Lys allele and Lys/Lys genotype of XPD Lys751Gln polymorphism may be a risk factor for LC and NPC. However, relatively modest sample sizes were included in this meta-analysis and studies with large sample sizes and representative population are warranted to further clarify this finding.
\end{abstract}

Virtual slides: The virtual slide(s) for this article can be found here: http://www.diagnosticpathology.diagnomx.eu/vs/ 5628716106316015.

Keywords: XPD, Polymorphism, Meta-analysis, Head and neck cancer

\section{Introduction}

Head and neck cancers (HNC) which involve malignant neoplasms of the oral cavity, pharynx, and larynx, are the sixth most common cancers threatening human life worldwide [1]. To date, there are ample evidences indicating that $\mathrm{HNC}$ is a complex multifactorial disorder involving genetic factors, lifestyle, tobacco smoke, alcohol consuming, and environmental factors [2-6] and some low-

\footnotetext{
*Correspondence: 96zheng@gmail.com

1 Department of Otorhinolaryngology, Eye and ENT Hospital of Fudan University, 83 Fenyang Road, Shanghai, Xuhui District 200031, China Full list of author information is available at the end of the article
}

penetrant genes have been identified as potential HNC susceptibility genes [7-9]. Among them, an important one is xeroderma pigmentosum group $\mathrm{D}(\mathrm{XPD})$ gene, which is located on chromosome 19q13.3. XPD gene, also known as excision repair cross-complementing group 2 (ERCC2) gene, encodes XPD protein, one ATP-dependent helicase within the multi subunit transcription repair factor complex,TFIIH, participates in DNA unwinding during the nucleotide excision repair (NER) pathway and plays a pivotal role in the recognition and repairment of structurally unrelated DNA lesions including bulky adducts and thymidine dimmers [10-12]. Dysregulation of DNA repair

\section{Ciomed Central}


proteins in NER pathways may be involved in pathogenesis of cancers [13,14].

The XPD Lys751Gln polymorphism (A35931C, rs13181 or rs1052559) is caused by A to C transition at codon 751 in exon 23 of XPD gene resulting in the Gln substitution for Lys. The XPD Lys751Gln polymorphism may lead to reduction in helicase activity and DNA repair capacity and may be important in the carcinogenesis and development of $\mathrm{HNC}[15,16]$.

To date, a series of case-control studies have been conducted to clarify the association between XPD Lys751Gln polymorphism and HNC risk. However, the results were inconsistent. Therefore, we performed this meta-analysis in order to precisely assess the possible association of XPD Lys751Gln with the susceptibility to develop HNC.

\section{Materials and methods}

\section{Search strategy}

The OVID, Medline, Embase,Pubmed, Web of Science databases (up to July 2013) were searched to identify the studies focusing on the association between XPD Lys751Gln polymorphism and susceptibility to HNC. The formats of search terms were used as follows: "xeroderma pigmentosum group D", "XPD", "excision repair cross-complementing group 2", "ERCC2", "head and neck cancer", "oral cancer", "pharyngeal cancer", "oropharyngeal cancer", "nasopharyngeal cancer", "laryngeal cancer", "SNP or polymorphism or variant" and the combination of them. The literature retrieval was performed by two authors (H. Lin and D. Lin) independently. Relevant reviews and abstracts of meetings were searched for related studies.

\section{Inclusion and exclusion criteria}

Eligible studies which satisfied the following inclusion criteria would be included: 1) the study clearly assessed the association between XPD Lys751Gln polymorphism and HNC risk; 2) HNC was diagnosed by histopathological examination; 3) the normal healthy controls had no diagnosis of HNC. On the other hand, the exclusion criteria was used as follows: 1) studies without normal healthy controls; 2) studies without essential data and information; 3) studies in which the genotype distributions in the controls significantly deviated from Hardy-Weinberg equilibrium (HWE).

\section{Data extraction}

Two authors (H. Lin and D. Lin) performed the extraction of relevant data respectively from all eligible studies. Disagreement was resolved by discussing between two authors (H. Lin and D. Lin). The relevant data as listed below were extracted: name of first author, publication year, country, ethnicity, source of controls, genotyping method, cancer type, total number of cancer patients and controls, and distribution of genotypes in these two groups and P-value of HWE tested in controls. The categorization of ethnicity comprised Caucasian and Asian. Source of controls was categorized as populationbased study, hospital-based study, nested case-control study and mixed study. The categorization of cancer type involved laryngeal cancer, oral cancer and nasopharyngeal cancer.

\section{Statistical analysis}

Pooled Odds ratios (ORs) with 95\% confidence intervals (CIs) were used to evaluate the association between XPD Lys751Gln polymorphism and susceptibility to $\mathrm{HNC}$ on the basis of the distinct genotype and allele frequencies of XPD Lys751Gln polymorphism in two groups. The five distinct genetic models comprised allele contrast (Gln v Lys), homozygous comparison (Gln/Gln $\mathrm{v}$ Lys/Lys), heterozygous comparison (Lys/Gln v Lys/ Lys), dominant model (Lys/Gln + Gln/Gln v Lys/Lys) and recessive model (Gln/Gln v Lys/Gln + Lys/Lys). We used $\mathrm{I}^{2}$ statistic to check heterogeneity. P-value of heterogeneity less than 0.1 was confirmed as statistically significant. The summary ORs were calculated under fixed effects model in the case that P-value of heterogeneity was more than 0.1 . Otherwise,we used random effects model to perform the data calculation. HWE in controls was assessed by the online program (http://ihg. gsf.de/cgi-bin/hw/hwa1.pl). Funnel plots,Begg's test and Egger's linear regression method were used to evaluate publication bias. $\mathrm{P}<0.05$ was confirmed as statistically significant to evaluate the data except heterogeneity test. We conducted subgroup analyses by stratification of ethnicity, source of controls and cancer type.In addition, sensitivity analysis was conducted to verify the impact of individual study respectively. All the data statistics and analyses were conducted using Stata version 12.0 (Stata Corporation, College Station, TX).

\section{Results}

\section{Study characteristics}

Selection process was summarized by the flow diagram in Figure 1. In summary, a total of 339 potentially relevant papers were identified after searching the OVID, Medline, Embase,Pubmed, Web of Science databases. Two authors (H. Lin and D. Lin) excluded ineligible articles independently. Then, 288 including duplicates or not related articles were excluded during screening. Then, fifty-one potentially relevant papers on XPD Lys751Gln polymorphism and susceptibility to HNC were selected. After careful examination of these papers, twenty-nine papers were excluded for the following reasons: seven were reviews, nine without normal healthy controls, two on cancers other than $\mathrm{HNC}$, one was overlapped study, eight on 


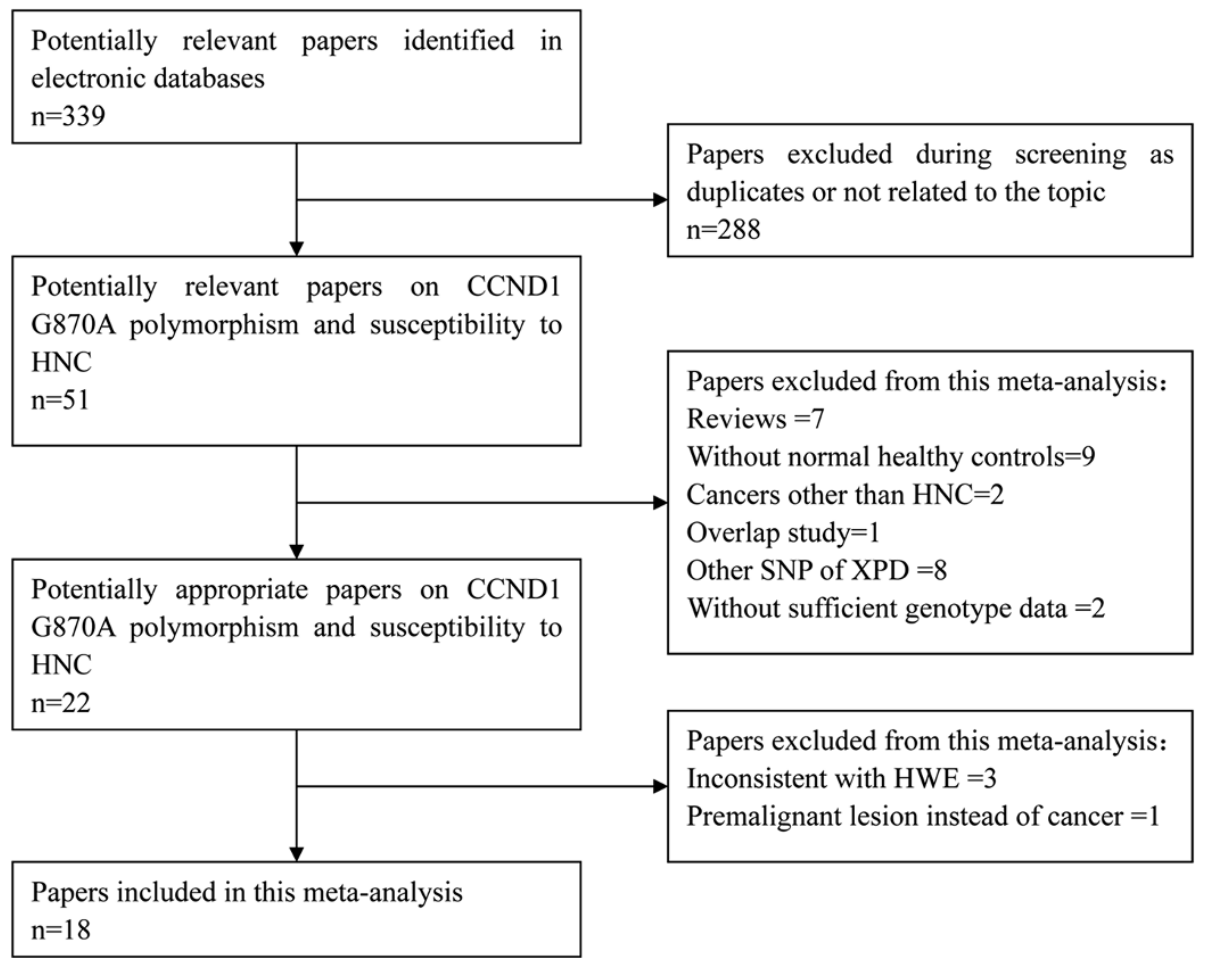

Figure 1 The flow diagram of included/excluded studies.

other SNP of XPD, two without sufficient genotype data. Then, twenty-two potentially appropriate papers reported the association of XPD Lys751Gln polymorphism with the risk of HNC. However, three papers [17-19] were excluded due to the genotype frequencies of control group being inconsistent with HWE and one paper [20] was ruled out for the study was focusing on premalignant lesion instead of cancer. As a result,eighteen eligible studies [21-38] with a total sample size of 4,510 HNC patients and 6,933 controls were included. In those included studies, eleven studies $[21-26,33-36,38]$ were performed in Caucasians and seven $[27-32,37]$ were conducted in Asians. Thirteen studies [21,22,24,26-28,31,33-38] were hospital-based, three studies $[29,30,32]$ were population-based and one [25] was nested case-control study and one study [23] conducted by Huang et al. was a pooled analysis comprised two population-based studies and one hospital-based study. The study conducted by Huang [23] recruited whites, blacks and others and had overall data of all subjects and white subjects. However, the genotype frequencies of controls in all subjects were inconsistent with HWE, so we only included white subjects. Two studies $[21,38]$ was performed on laryngeal cancer, three studies [27,31,37] on oral cancer, one [29] on nasopharyngeal cancer and twelve studies [22-26,28,30,32-36] on head and neck cancers. We only included six studies $[21,27,29,31,37,38]$ having detailed genotype data of laryngeal cancer, oral cancer and nasopharyngeal cancer for subgroup analysis by cancer type. Consequently, we performed subgroup analysis by stratification of ethnicity, source of controls and cancer type. Details of subjects in these studies were outlined in Table 1.

\section{Association between XPD Lys751GIn polymorphism and susceptibility to HNC}

The main results of our meta-analysis under five distinct genetic models were listed in Table 2. Overall, XPD Lys $751 \mathrm{Gln}$ polymorphism had no association with increased HNC risk under all five genetic models (allele contrast: $\mathrm{OR}=1.05,95 \% \mathrm{CI}=0.95-1.18, \mathrm{P}=0.337$, Figure 2; homozygous comparison: $\mathrm{OR}=1.18,95 \% \mathrm{CI}=0.96$ $1.45, \mathrm{P}=0.118$; heterozygous comparison: $\mathrm{OR}=1.02$, $95 \% \mathrm{CI}=0.90-1.17, \mathrm{P}=0.725$; dominant model: $\mathrm{OR}=1.05$, $95 \% \mathrm{CI}=0.91-1.21 ; \mathrm{P}=0.538$; recessive model: $\mathrm{OR}=1.11$, $95 \% \mathrm{CI}=0.98-1.26, \mathrm{P}=0.112$ ).

In the subgroup analysis by ethnicity and source of controls, still no significant association was found (Figure 2, Table 2).

In the subgroup analysis by cancer type, XPD Lys7 $51 \mathrm{Gln}$ polymorphism had statistically significant association with elevated laryngeal cancer (LC) and nasopharyngeal cancer (NPC) risk under heterozygous comparison and dominant model $(\mathrm{P}<0.05$, Figure 3 , Table 2$)$ and borderline significantly increased risk was found under allele contrast for $\mathrm{LC}(\mathrm{OR}=0.82,95 \% \mathrm{CI}=0.67-1.00, \mathrm{P}=0.056)$ and NPC $(\mathrm{OR}=0.60,95 \% \mathrm{CI}=0.36-1.00, \mathrm{P}=0.05)$. 
Table 1 Characteristics of included studies

\begin{tabular}{|c|c|c|c|c|c|c|c|c|c|c|c|c|c|c|c|}
\hline \multirow[t]{2}{*}{ Author } & \multirow[t]{2}{*}{ Year } & \multirow[t]{2}{*}{ Country } & \multirow[t]{2}{*}{ Ethnicity } & \multirow[t]{2}{*}{ Source } & \multirow{2}{*}{$\begin{array}{l}\text { Genotyping } \\
\text { method }\end{array}$} & \multirow{2}{*}{$\begin{array}{l}\text { Cancer } \\
\text { type }\end{array}$} & \multicolumn{2}{|c|}{ Total number } & \multicolumn{3}{|c|}{ Cases } & \multicolumn{3}{|c|}{ Controls } & \multirow{2}{*}{$\begin{array}{l}\text { HWE of } \\
\text { controls }\end{array}$} \\
\hline & & & & & & & Cases & Controls & $\begin{array}{l}\text { Lys/ } \\
\text { Lys }\end{array}$ & $\begin{array}{l}\text { Lys/ } \\
\text { Gln }\end{array}$ & $\begin{array}{l}\mathrm{Gln} / \\
\mathrm{Gln}\end{array}$ & $\begin{array}{l}\text { Lys/ } \\
\text { Lys }\end{array}$ & $\begin{array}{l}\text { Lys/ } \\
\text { Gln }\end{array}$ & $\begin{array}{l}\mathrm{Gln} / \\
\mathrm{Gln}\end{array}$ & \\
\hline Sturgis [26] & 2000 & America & Caucasian & $\mathrm{HB}$ & PCR-RFLP & $\mathrm{SCCHN}$ & 189 & 496 & 75 & 83 & 31 & 218 & 221 & 57 & 0.9304 \\
\hline Gajecka [21] & 2005 & Poland & Caucasian & $\mathrm{HB}$ & PCR-RFLP & LC & 293 & 320 & 110 & 135 & 48 & 87 & 175 & 58 & 0.0659 \\
\hline Huang [23] & 2005 & America & Caucasian & $M i x^{*}$ & TaqMan-PCR & HNC & 425 & 683 & 176 & 188 & 61 & 296 & 292 & 95 & 0.0951 \\
\hline Rydzanicz [24] & 2005 & Poland & Caucasian & $\mathrm{HB}$ & PCR-RFLP & HNC & 172 & 143 & 69 & 73 & 30 & 54 & 64 & 25 & 0.4265 \\
\hline $\begin{array}{l}\text { Kietthubthew } \\
\text { [32] }\end{array}$ & 2006 & Thailand & Asian & PB & PCR-RFLP & sccoc & 105 & 164 & 83 & 21 & 1 & 126 & 36 & 2 & 0.7489 \\
\hline Matullo [25] & 2006 & Europe & Caucasian & nest & TaqMan-PCR & UADC & 82 & 1094 & 34 & 39 & 9 & 397 & 504 & 193 & 0.1330 \\
\hline $\begin{array}{l}\text { Ramachandran } \\
\text { [37] }\end{array}$ & 2006 & India & Asian & $H B$ & PCR-RFLP & OC & 110 & 110 & 49 & 46 & 15 & 71 & 31 & 8 & 0.0908 \\
\hline n [22] & 2007 & America & Caucasian & $\mathrm{HB}$ & PCR-RFLP & $\mathrm{SCCHN}$ & 829 & 854 & 330 & 394 & 105 & 358 & 386 & 110 & 0.7091 \\
\hline Bau [27] & 2007 & Taiwan & Asian & $\mathrm{HB}$ & PCR-RFLP & OC & 154 & 105 & 134 & 18 & 2 & 89 & 15 & 1 & 0.6824 \\
\hline Yang [29] & 2007 & China & Asian & PB & PCR-RFLP & NPC & 153 & 168 & 128 & 24 & 1 & 124 & 43 & 1 & 0.1805 \\
\hline Majumder [31] & 2007 & India & Asian & $H B$ & PCR-RFLP & OC & 309 & 388 & 158 & 125 & 26 & 190 & 158 & 40 & 0.4030 \\
\hline Harth [35] & 2008 & Germany & Caucasian & $\mathrm{HB}$ & PCR-RFLP & $\mathrm{SCCHN}$ & 312 & 300 & 111 & 154 & 47 & 108 & 149 & 43 & 0.4642 \\
\hline Mitra [34] & 2009 & $\begin{array}{l}\text { North } \\
\text { India }\end{array}$ & Caucasian & $H B$ & PCR-RFLP & $\mathrm{SCCHN}$ & 275 & 385 & 88 & 148 & 39 & 163 & 179 & 43 & 0.5571 \\
\hline Jelonek [33] & 2010 & Poland & Caucasian & $H B$ & PCR-RFLP & HNC & 103 & 110 & 29 & 52 & 22 & 38 & 60 & 12 & 0.1030 \\
\hline Ji [28] & 2010 & Korea & Asian & $H B$ & PCR-SBE & $\mathrm{SCCHN}$ & 267 & 348 & 232 & 32 & 3 & 298 & 48 & 2 & 0.9645 \\
\hline Stembalska [38] & 2011 & Poland & Caucasian & $\mathrm{HB}$ & PCR-RFLP & LSCC & 60 & 100 & 20 & 26 & 14 & 32 & 46 & 22 & 0.4795 \\
\hline Kumar [36] & 2012 & $\begin{array}{l}\text { North } \\
\text { India }\end{array}$ & Caucasian & $H B$ & PCR-RFLP & $\mathrm{SCCHN}$ & 278 & 278 & 92 & 125 & 61 & 129 & 110 & 39 & 0.0531 \\
\hline Yuan [30] & 2012 & China & Asian & PB & TaqMan-PCR & $\mathrm{HNC}$ & 394 & 887 & 333 & 57 & 4 & 752 & 129 & 6 & 0.8556 \\
\hline
\end{tabular}

Table 2 Main results of pooled ORs in this meta-analysis

\begin{tabular}{|c|c|c|c|c|c|c|c|c|c|c|c|}
\hline \multirow[t]{2}{*}{ Study groups } & \multirow[t]{2}{*}{$\mathrm{n}$} & \multicolumn{2}{|c|}{ Gln v Lys } & \multicolumn{2}{|c|}{ Gln/GIn v Lys/Lys } & \multicolumn{2}{|c|}{ Lys/GIn v Lys/Lys } & \multicolumn{2}{|c|}{$\begin{array}{c}\text { Lys/GIn + Gln/GIn v } \\
\text { Lys/Lys }\end{array}$} & \multicolumn{2}{|c|}{$\begin{array}{c}\text { Gln/GIn v Lys/Lys + } \\
\text { Lys/Gln }\end{array}$} \\
\hline & & OR $(95 \% \mathrm{Cl})$ & $\mathrm{Ph}$ & OR $(95 \% \mathrm{Cl})$ & $\mathrm{Ph}$ & OR $(95 \% \mathrm{Cl})$ & $\mathrm{Ph}$ & OR $(95 \% \mathrm{Cl})$ & $\mathrm{Ph}$ & OR $(95 \% \mathrm{Cl})$ & $\mathrm{Ph}$ \\
\hline All & 18 & 1.05(0.95-1.18) & $<0.001$ & $1.18(0.96-1.45)$ & 0.030 & $1.02(0.90-1.17)$ & 0.011 & $1.05(0.91-1.21)$ & 0.001 & $1.11(0.98-1.26)$ & 0.359 \\
\hline Ethnicity & 18 & & & & & & & & & & \\
\hline Caucasian & 11 & $1.08(0.96-1.23)$ & 0.002 & $1.17(0.92-1.49)$ & 0.008 & $1.06(0.91-1.25)$ & 0.033 & $1.09(0.92-1.29)$ & 0.004 & $1.11(0.97-1.27)$ & 0.150 \\
\hline Asian & 7 & $0.99(0.78-1.26)$ & 0.026 & $1.13(0.75-1.70)$ & 0.437 & $0.95(0.73-1.23)$ & 0.062 & $0.97(0.74-1.27)$ & 0.028 & $1.09(0.74-1.60)$ & 0.687 \\
\hline \multicolumn{12}{|l|}{ Source } \\
\hline $\mathrm{HB}$ & 13 & $1.11(0.98-1.27)$ & 0.001 & $1.26(0.98-1.61)$ & 0.014 & $1.07(0.91-1.27)$ & 0.009 & $1.11(0.93-1.33)$ & 0.001 & $1.16(1.00-1.33)$ & 0.273 \\
\hline Mix & 1 & $1.05(0.88-1.26)$ & - & $1.08(0.74-1.57)$ & - & $1.08(0.83-1.41)$ & - & $1.08(0.85-1.38)$ & - & $1.04(0.73-1.47)$ & - \\
\hline PB & 3 & $0.86(0.62-1.19)$ & 0.193 & $1.25(0.44-3.54)$ & 0.870 & $0.82(0.57-1.18)$ & 0.181 & $0.83(0.57-1.19)$ & 0.168 & $1.26(0.45-3.57)$ & 0.888 \\
\hline nest & 1 & $0.78(0.56-1.08)$ & - & $0.54(0.26-1.16)$ & - & $0.90(0.56-1.46)$ & - & $0.80(0.51-1.27)$ & - & $0.58(0.28-1.17)$ & - \\
\hline Cancer type & 6 & $0.95(0.72-1.25)$ & 0.005 & $0.88(0.65-1.18)$ & 0.185 & $0.87(0.60-1.27)$ & 0.007 & $0.90(0.61-1.31)$ & 0.002 & $0.97(0.73-1.28)$ & 0.640 \\
\hline $\mathrm{LC}$ & 2 & $0.72(0.48-1.10)$ & 0.339 & $0.72(0.48-1.10)$ & 0.383 & $0.66(0.48-0.91)$ & 0.347 & $0.69(0.48-0.97)$ & 0.285 & $0.93(0.64-1.34)$ & 0.655 \\
\hline OC & 3 & $1.16(0.68-1.98)$ & 0.007 & 1.08(0.69-1.69) & 0.075 & $1.18(0.67-2.05)$ & 0.036 & $1.20(0.65-2.21)$ & 0.012 & $1.02(0.66-1.58)$ & 0.213 \\
\hline NPC & 1 & $0.60(0.36-1.00)$ & - & 0.97(0.06-15.66) & - & $0.54(0.31-0.94)$ & - & $0.55(0.32-0.95)$ & - & $1.10(0.07-17.72)$ & - \\
\hline
\end{tabular}




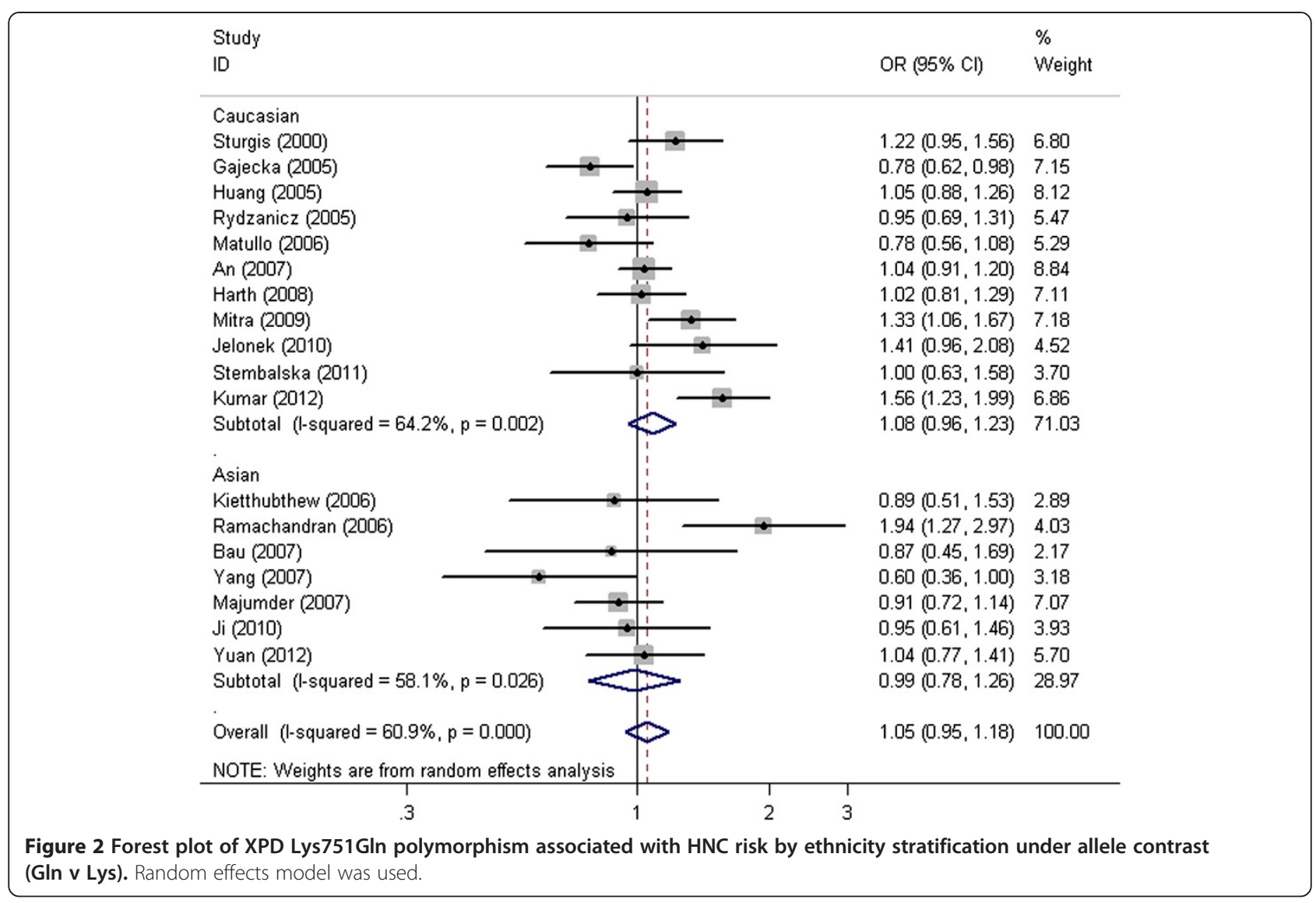

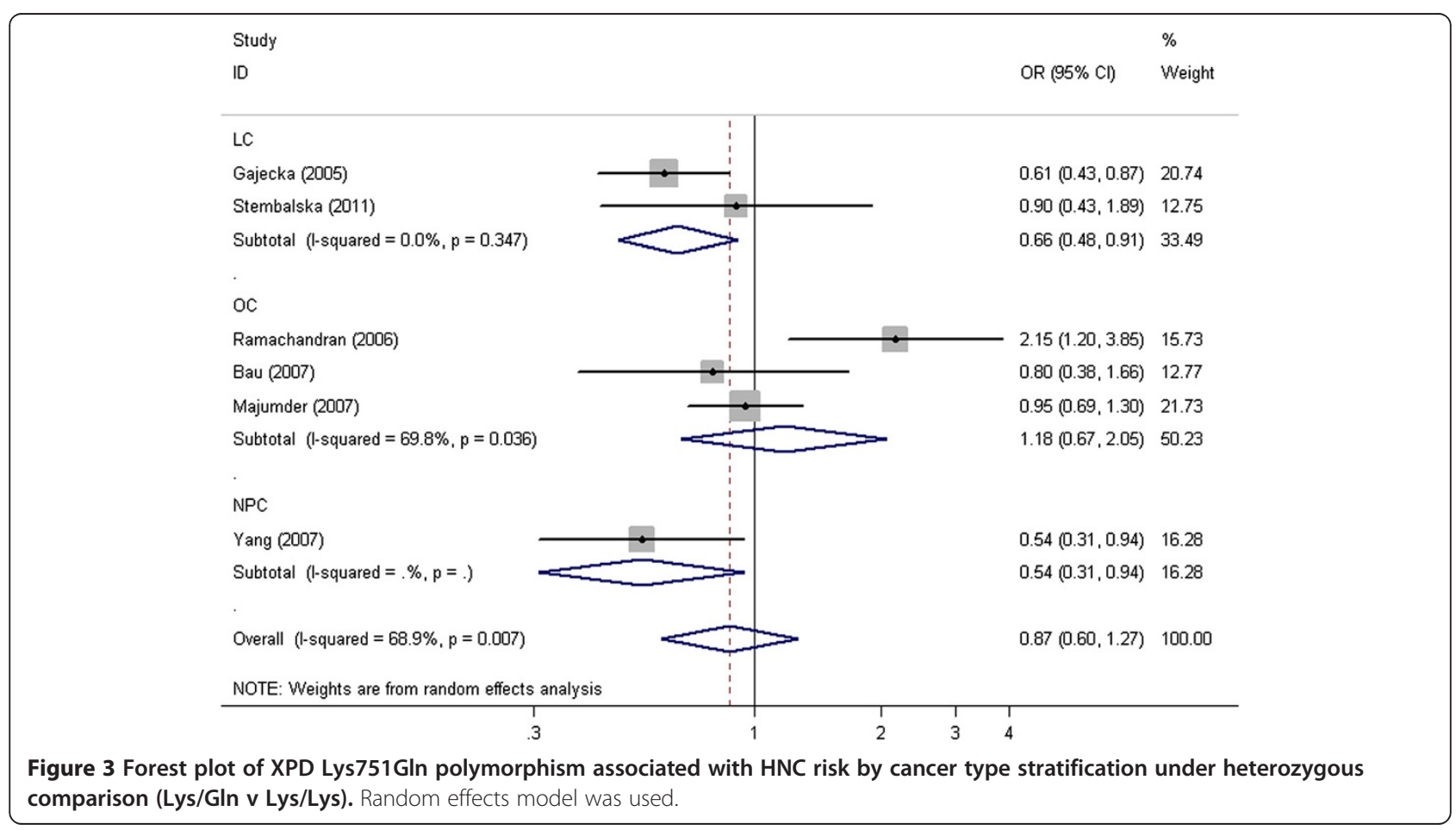




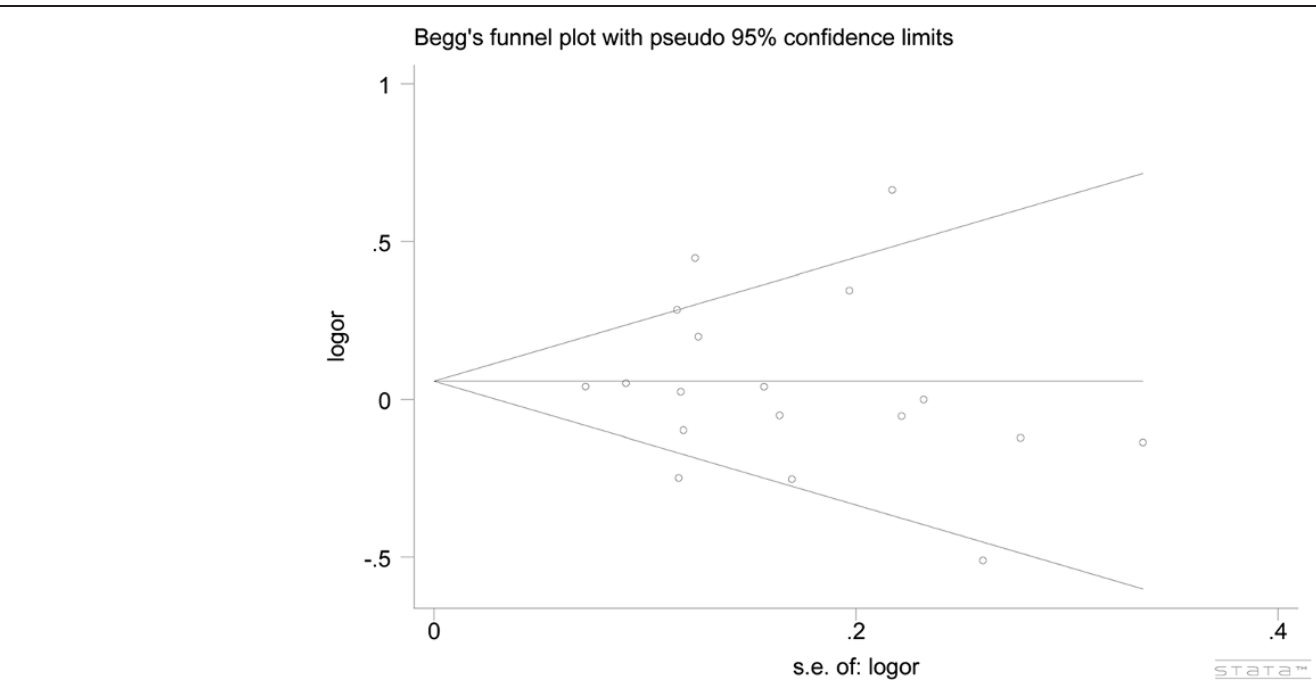

Figure 4 Begg's funnel plot with pseudo-95\% confidence limits under allele contrast (Gln v Lys). Each small circle represents a separate study for the indicated association.

Carriers of Lys allele and Lys/Lys genotype were more likely to have LC or NPC.

\section{Heterogeneity and publication bias}

There were no significant heterogeneities for the overall analysis under recessive model and the subgroup analysis by cancer type under homozygous comparison and recessive model $(\mathrm{Ph}>0.10$, Table 2$)$, so the results were assessed under fixed effects model. However, there were some significant heterogeneities for the overall analysis under allele contrast, homozygous comparison, heterozygous comparison and dominant model and the subgroup analysis by cancer type under allele contrast, heterozygous comparison and dominant model $(\mathrm{Ph}<0.10$, Table 2$)$. Hence, the results were assessed under random effects model.

In this meta-analysis, we used both funnel plots, Begg's test and Egger's linear regression method to evaluate the publication bias. There were no obvious asymmetry in the funnel plots. Meanwhile, results of Begg's test and Eggers's linear regression method indicated that there were no obvious publication bias ( $\mathrm{P}>0.05$, Figure 4 ).

\section{Sensitivity analysis}

Sensitivity analysis was performed to reflect the impact of the individual study to the summarized ORs by removing one study each time involved in the meta-analysis.

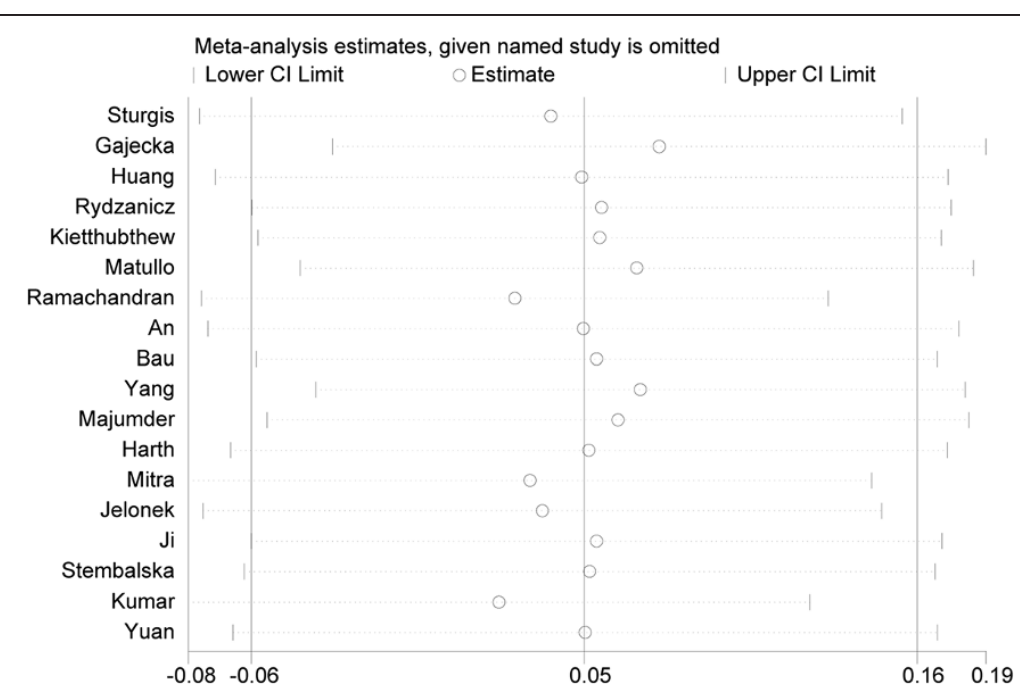

Figure 5 The result of sensitive analysis under allele contrast (Gln v Lys). This figure shows the influence of individual studies on the summary OR. The middle vertical axis indicates the overall OR, and the two vertical axes indicate the pooled OR when the left study is omitted from the meta-analysis. The two ends of the dotted lines represent the $95 \% \mathrm{Cl}$. 
We found that the summarized ORs with 95\% CIs under all genetic models were not significantly altered after sensitivity analysis (Figure 5), indicating that our results were stable and statistically robust.

\section{Discussion}

It has been shown that XPD acting as a key DNA repair protein in the NER pathway is involved in the pathogenesis of cancer and XPD Lys751Gln polymorphism may be involved in the mechanism of carcinogenesis $b$ [39]. To date, different studies on the association between XPD Lys751Gln polymorphism and HNC risk have showed discrepant results. Thus, our meta-analysis from eighteen studies comprising 4,510 HNC patients and 6,933 controls was performed to precisely assess the possible association of XPD Lys751Gln polymorphism with the susceptibility to develop HNC.

Our meta-analysis, which comprised 4,510 HNC patients and 6,933 controls, indicated the following descriptions: first, XPD Lys751Gln polymorphism had no association with increased $\mathrm{HNC}$ risk under all five genetic models by overall analysis; second, still no significant association was found under five genetic models in the subgroup analysis by ethnicity and source of controls;third, XPD Lys751Gln polymorphism had statistically significant association with elevated LC and NPC risk under heterozygous comparison and dominant model and borderline significantly increased risk was found under allele contrast for LC and NPC. The Lys allele and Lys/Lys genotype of XPD Lys751Gln polymorphism may be a risk factor for LC and NPC.

Some limitations of our study should be interpreted. First, the included studies were carried out mainly in Caucasians and Asians and only three studies were population-based, which increased the limitation of statistical power. Hence, studies with larger sample sizes and representative population should be warranted to verify our findings. Second, we only included published papers, as a result, there may be publication bias across studies, although Begg's test, Egger's linear regression method did not show any conspicuous publication bias. Finally, our results were grounded on unadjusted estimates, however, XPD Lys751Gln polymorphism is only one phenotype of $\mathrm{HNC}$ and $\mathrm{HNC}$ is an intricate disorder, and there are many other factors comprising genes, occupation, lifestyle, gender, a history of smoking or drinking, obesity and environmental factors participating in the development of HNC. If the individual data including confounding factors mentioned above were available, a more precise analysis allowing for the adjustment by other covariants should be performed in the future.

\section{Conclusion}

In conclusion, there is overall lack of association between XPD Lys751Gln polymorphism and HNC risk under all five genetic models and still no significant association was found in the subgroup analysis by ethnicity and source of controls. However, XPD Lys751Gln polymorphism was significantly associated with susceptibility to LC and NPC. Carriers of Lys allele and Lys/Lys genotype may be associated with elevated LC and NPC risk. The Lys allele and Lys/Lys genotype of XPD Lys751Gln polymorphism may be a risk factor for LC and NPC. However, relatively modest sample sizes were included in this meta-analysis and studies with large sample sizes and representative population are warranted to further clarify this finding.

\section{Abbreviations \\ XPD: Xeroderma pigmentosum group D; SNP: Single nucleotide polymorphism; HNC: Head and neck cancer; LC: Laryngeal cancer; OC: Oral cancer; NPC: Nasopharyngeal cancer; OR: Odds ratio; Cl: Confidence interval; HWE: Hardy- Weinberg equilibrium.}

\section{Competing interests}

The authors declare that they have no competing interests.

\section{Authors' contributions}

$H L$ and DL carried out the meta-analysis study, drafted the manuscript and involved in revising the manuscript critically for important intellectual content. CZ and HL participated in the design of the study and revised the manuscript. All authors read and approved the final manuscript.

\section{Author details}

'Department of Otorhinolaryngology, Eye and ENT Hospital of Fudan University, 83 Fenyang Road, Shanghai, Xuhui District 200031, China ${ }^{2}$ Department of Biology and Chemical Engineering, Fuqing Branch of Fujian Normal University, Fuqing, Fujian 350300, China.

Received: 22 August 2013 Accepted: 27 December 2013 Published: 20 January 2014

\section{References}

1. Jemal A, Siegel R, Xu J, Ward E: Cancer statistics, 2010. CA Cancer J Clin 2010, 60:277-300.

2. Smith EM, Rubenstein LM, Haugen TH, Pawlita M, Turek LP: Complex etiology underlies risk and survival in head and neck cancer human papillomavirus, tobacco, and alcohol: a case for multifactor disease. J Oncol 2012, 2012:571862.

3. Mokhtari S: Mechanisms of cyst formation in metastatic lymph nodes of head and neck squamous cell carcinoma. Diagn Pathol 2012, 7:6.

4. Liu Y, Dong XL, Tian C, Liu HG: Human telomerase RNA component (hTERC) gene amplification detected by FISH in precancerous lesions and carcinoma of the larynx. Diagn Pathol 2012, 7:34.

5. Arora S, Aggarwal P, Pathak A, Bhandari R, Duffoo F, Gulati SC: Molecular genetics of head and neck cancer (Review). Mol Med Rep 2012, 6:19-22.

6. Shamaa AA, Zyada MM, Wagner M, Awad SS, Osman MM, Abdel Azeem AA: The significance of Epstein Barr virus (EBV) \& DNA topoisomerase II alpha (DNA-Topo II alpha) immunoreactivity in normal oral mucosa, oral epithelial dysplasia (OED) and oral squamous cell carcinoma (OSCC). Diagn Pathol 2008, 3:45.

7. Hopkins J, Cescon DW, Tse D, Bradbury P, Xu W, Ma C, Wheatley-Price P, Waldron J, Goldstein D, Meyer F, et al: Genetic polymorphisms and head and neck cancer outcomes: a review. Cancer Epidemiol Biomarkers Prev 2008, 17:490-499.

8. Ruiz MT, Galbiatti AL, Pavarino EC, Maniglia JV, Goloni-Bertollo EM: Q36R polymorphism of KiSS-1 gene in Brazilian head and neck cancer patients. Mol Biol Rep 2012, 39:6029-6034.

9. Zhang Y, Bai Y, Zhang Y, Guan J, Chen L: The MDM2 309 T/G polymorphism is associated with head and neck cancer risk especially in nasopharyngeal cancer: a meta-analysis. Onkologie 2012, 35:666-670.

10. Alanazi M, Pathan AA, Ajaj SA, Khan W, Shaik JP, Al Tassan N, Parine NR: DNA repair genes XRCC1, XRCC3, XPD, and OGG1 polymorphisms 
among the central region population of Saudi Arabia. Biol Res 2013, 46:161-167.

11. Benhamou S, Sarasin A: ERCC2/XPD gene polymorphisms and cancer risk. Mutagenesis 2002, 17:463-469.

12. Ouyang FD, Yang FL, Chen HC, Khan MA, Huang FM, Wan XX, Xu AH, Huang X, Zhou MJ, Fang Q, Zhang DZ: Polymorphisms of DNA repair genes XPD, XRCC1, and OGG1, and lung adenocarcinoma susceptibility in Chinese population. Tumour Biol 2013, 34:2843-2848.

13. Artac M, Bozcuk H, Pehlivan S, Akcan S, Pehlivan M, Sever T, Ozdogan M, Savas B: The value of XPD and XRCC1 genotype polymorphisms to predict clinical outcome in metastatic colorectal carcinoma patients with irinotecan-based regimens. J Cancer Res Clin Oncol 2010, 136:803-809.

14. Chang CH, Wang RF, Tsai RY, Wu HC, Wang CH, Tsai CW, Chang CL, Tsou YA, Liu CS, Bau DT: Significant association of XPD codon 312 single nucleotide polymorphism with bladder cancer susceptibility in Taiwan. Anticancer Res 2009, 29:3903-3907.

15. Wang M, Chu H, Zhang Z, Wei Q: Molecular epidemiology of DNA repair gene polymorphisms and head and neck cancer. J Biomed Res 2013, 27:179-192.

16. Flores-Obando RE, Gollin SM, Ragin CC: Polymorphisms in DNA damage response genes and head and neck cancer risk. Biomarkers 2010, 15:379-399.

17. Abbasi R, Ramroth $H$, Becher $H$, Dietz A, Schmezer P, Popanda O: Laryngeal cancer risk associated with smoking and alcohol consumption is modified by genetic polymorphisms in ERCC5, ERCC 6 and RAD23B but not by polymorphisms in five other nucleotide excision repair genes. Int J Cancer 2009, 125:1431-1439.

18. Gugatschka M, Dehchamani D, Wascher TC, Friedrich G, Renner W: DNA repair gene ERCC2 polymorphisms and risk of squamous cell carcinoma of the head and neck. Exp Mol Pathol 2011, 91:331-334.

19. Sliwinski T, Przybylowska K, Markiewicz L, Rusin P, Pietruszewska W, ZelinskaBlizniewska H, Olszewski J, Morawiec-Sztandera A, Mlynarski W, Majsterek I: MUTYH Tyr165Cys, OGG1 Ser326Cys and XPD Lys751Gln polymorphisms and head neck cancer susceptibility: a case control study. Mol Biol Rep 2011, 38:1251-1261.

20. Wang Y, Spitz MR, Lee JJ, Huang M, Lippman SM, Wu X: Nucleotide excision repair pathway genes and oral premalignant lesions. Clin Cancer Res 2007, 13:3753-3758.

21. Gajecka M, Rydzanicz M, Jaskula-Sztul R, Wierzbicka M, Szyfter W, Szyfter K: Reduced DNA repair capacity in laryngeal cancer subjects. A comparison of phenotypic and genotypic results. Adv Otorhinolaryngol 2005, 62:25-37.

22. An J, Liu Z, Hu Z, Li G, Wang LE, Sturgis EM, El-Naggar AK, Spitz MR, Wei Q: Potentially functional single nucleotide polymorphisms in the core nucleotide excision repair genes and risk of squamous cell carcinoma of the head and neck. Cancer Epidemiol Biomarkers Prev 2007, 16:1633-1638.

23. Huang WY, Olshan AF, Schwartz SM, Berndt SI, Chen C, Llaca V, Chanock SJ, Fraumeni JF Jr, Hayes RB: Selected genetic polymorphisms in MGMT, XRCC1, XPD, and XRCC3 and risk of head and neck cancer: a pooled analysis. Cancer Epidemiol Biomarkers Prev 2005, 14:1747-1753.

24. Rydzanicz M, Wierzbicka M, Gajecka M, Szyfter W, Szyfter K: The impact of genetic factors on the incidence of multiple primary tumors (MPT) of the head and neck. Cancer Lett 2005, 224:263-278.

25. Matullo G, Dunning AM, Guarrera S, Baynes C, Polidoro S, Garte S, Autrup H, Malaveille C, Peluso M, Airoldi L, et al: DNA repair polymorphisms and cancer risk in non-smokers in a cohort study. Carcinogenesis 2006, 27:997-1007.

26. Sturgis EM, Zheng R, Li L, Castillo EJ, Eicher SA, Chen M, Strom SS, Spitz MR, Wei Q: XPD/ERCC2 polymorphisms and risk of head and neck cancer: a case-control analysis. Carcinogenesis 2000, 21:2219-2223.

27. Bau DT, Tsai MH, Huang CY, Lee CC, Tseng HC, Lo YL, Tsai Y, Tsai FJ: Relationship between polymorphisms of nucleotide excision repair genes and oral cancer risk in Taiwan: evidence for modification of smoking habit. Chin J Physiol 2007, 50:294-300.

28. Ji YB, Tae K, Lee YS, Lee SH, Kim KR, Park CW, Park BL, Shin HD: XPD polymorphisms and risk of squamous cell carcinoma of the head and neck in a Korean sample. Clin Exp Otorhinolaryngol 2010, 3:42-47.

29. Yang ZH, Du B, Wei YS, Zhang JH, Zhou B, Liang WB, Jia J, Zhang BL, Zhang $L$ : Genetic polymorphisms of the DNA repair gene and risk of nasopharyngeal carcinoma. DNA Cell Biol 2007, 26:491-496.
30. Yuan H, Li H, Ma H, Niu Y, Wu Y, Zhang S, Hu Z, Shen H, Chen N: Genetic polymorphisms in key DNA repair genes and risk of head and neck cancer in a Chinese population. Exp Ther Med 2012, 3:719-724.

31. Majumder M, Sikdar N, Ghosh S, Roy B: Polymorphisms at XPD and XRCC1 DNA repair loci and increased risk of oral leukoplakia and cancer among NAT2 slow acetylators. Int J Cancer 2007, 120:2148-2156.

32. Kietthubthew S, Sriplung H, Au WW, Ishida T: Polymorphism in DNA repair genes and oral squamous cell carcinoma in Thailand. Int J Hyg Environ Health 2006, 209:21-29.

33. Jelonek K, Gdowicz-Klosok A, Pietrowska M, Borkowska M, Korfanty J, Rzeszowska-Wolny J, Widlak P: Association between single-nucleotide polymorphisms of selected genes involved in the response to DNA damage and risk of colon, head and neck, and breast cancers in a Polish population. J Appl Genet 2010, 51:343-352.

34. Mitra AK, Singh N, Garg VK, Chaturvedi R, Sharma M, Rath SK: Statistically significant association of the single nucleotide polymorphism (SNP) rs13181 (ERCC2) with predisposition to Squamous Cell Carcinomas of the Head and Neck (SCCHN) and Breast cancer in the north Indian population. J Exp Clin Cancer Res 2009, 28:104

35. Harth V, Schafer M, Abel J, Maintz L, Neuhaus T, Besuden M, Primke R, Wilkesmann A, Thier $\mathrm{R}$, Vetter $\mathrm{H}$, et al: Head and neck squamous-cell cancer and its association with polymorphic enzymes of xenobiotic metabolism and repair. J Toxicol Environ Health A 2008, 71:887-897.

36. Kumar A, Pant MC, Singh HS, Khandelwal S: Associated risk of XRCC1 and XPD cross talk and life style factors in progression of head and neck cancer in north Indian population. Mutat Res 2012, 729:24-34.

37. Ramachandran S, Ramadas K, Hariharan R, Rejnish Kumar R, Radhakrishna Pillai M: Single nucleotide polymorphisms of DNA repair genes XRCC1 and XPD and its molecular mapping in Indian oral cancer. Oral Oncol 2006, 42:350-362.

38. Stembalska A, Gil J, Łaczmańska I, Ramsey D, Leszczyński P, Kaczmarek D, Trusewicz A, Jagas M, Frączek M: The role of chosen polymorphisms in genes coding xenobiotic metabolizing enzymes and DNA repair proteins in laryngeal cancers. Adv Clin Exp Med 2011, 20:583-590.

39. Goode EL, Ulrich CM, Potter JD: Polymorphisms in DNA repair genes and associations with cancer risk. Cancer Epidemiol Biomarkers Prev 2002, 11:1513-1530.

doi:10.1186/1746-1596-9-15

Cite this article as: Lin et al.: Association of XPD Lys751GIn

polymorphism with head and neck cancer susceptibility: evidence from 11,443 subjects. Diagnostic Pathology 2014 9:15.

\section{Submit your next manuscript to BioMed Central and take full advantage of:}

- Convenient online submission

- Thorough peer review

- No space constraints or color figure charges

- Immediate publication on acceptance

- Inclusion in PubMed, CAS, Scopus and Google Scholar

- Research which is freely available for redistribution 